\title{
SOCIAL CLASS AND DELINQUENCY
}

\author{
AN EMPIRICAL UTILIZATION OF RATIONAL CHOICE \\ THEORY WITH CROSS-SECTIONAL DATA OF THE \\ 1990 AND 2000 GERMAN GENERAL POPULATION \\ SURVEYS (ALLBUS)
}

\section{Rolf Becker and Guido Mehlkop}

\begin{abstract}
The frequently predicted relationship between social class and criminal behavior is theoretically vacillating and empirically exiguous. We present an extended rational choice model which integrates the effects of an individual's social status on his or her subjective evaluations of (1) costs, (2) utility, (3) the probability of apprehension, (4) the selective incentives, and (5) the internalization of social norms. We test the model against the offences of shoplifting and tax-evasion. The data source derived from the German General Social Survey empirically supports the theoretical model. There exists no prevalent relationship between an individual's social status and his or her incentives towards criminal comportment. However, the social status of an individual affects the type of offences committed. The subjectively expected probability of either failing or succeeding in a criminal act takes greater precedence over the fear of retribution or the expected utility. Additionally, internalized norms decrease the probability of committing a crime.
\end{abstract}

KEY WORDS $\bullet$ deviant behavior $\bullet$ crime $\bullet$ rational choice theory

- social structure

\section{Introduction}

Despite inconsistent findings, sociology and criminology still work on the assumption that there exists a relationship between social status and delinquent behavior (Dunaway et al. 2000; Hindelang et al. 1979: 1002; Tittle and Meier 1990). ${ }^{1}$ Undeniably, there exist elements within lower socioeconomic groups that are prone towards

Rationality and Society Copyright (c) 2006 Sage Publications. Vol. 18(2): 193-235. www.sagepublications.com DOI: 10.1177/1043463106063323 
criminal conduct, when compared to the privileged classes (Tittle et al. 1978). ${ }^{2}$ Conversely, this phenomenon evanesces if the empirical analysis distinguishes between different criminal offences (Tittle and Meier 1990: 272). Apart from the empirical difficulties, there exist theoretical doubts regarding the negative relationship between one's socioeconomic status (SES) and criminality (Tittle 1983: 353). It remains unclear whether and in what circumstances this negative relationship exists (Tittle and Meier 1990: 271-2). Finally, there exists no consistent theory which is capable of explaining this phenomenon completely. A theoretically coherent proposition system is needed to systematically integrate each respective observation and provide a causal explanation regarding criminal behavior, in correlation to social status.

The Theory of Anomie (Merton 1968) and its further development into the Theory of Opportunity Structure (Cloward 1968) categorize criminality as a lack of access to legitimate means of attaining socially determined aims. Consequently, criminality of the less privileged class is examined. In their Theory of Differential Association, Sutherland and Cressey (1966) postulate that criminal motives and techniques are learned within a reference group and in the case of so-called 'white collar' criminality, the legal occupation often constitutes the best learning milieu (Coleman 1985). Yet, these approaches fail, in principle, to state the reason as to why (under similar socioeconomic conditions) some individuals become miscreant, whereas others remain desensitized. How mainly positive assessments of differing behavior within a group originally came about is also left unanswered (Opp 1974: 164, 1989: 409-10; Sykes 1978: 270). Additionally, these theories neither display foundational characteristics of the social theory of action, nor do they name relevant social mechanisms of criminal behavior (Hedström and Swedberg 1996). Furthermore, the reference to an insufficient internalization of aims and means, owing to a socialization which leads to a deficit of internalized norms, constitutes an argument which requires explanation (Tittle 1983). Thus, these approaches involve the danger of ending in a so-called 'variable sociology' (Esser 1996a) if delinquent behavior is an exclusive comparison amongst the social classes.

These three theories imply a relationship between social status and criminality. However, they are incomplete since they do not explain the (social) circumstances under which a criminal act is committed and why a large number of individuals display law-abiding behavior. Gary S. Becker's 'Economic Theory of Crime' offers a respite 
from this theoretical deficiency (e.g. McCarthy 2002; McKenzie and Tullock 1984; Opp 1989). ${ }^{3}$ According to Becker (1968), criminality is the consequence of a rational mind's decision to maximize benefit. Thus, offenders are not victims of social conditions, but practice the intentional maximization of advantages, such as physical wellbeing or social recognition, through criminal acts, and henceforth ascertain that their illegal conduct yields no adversarial consequences. In this respect, criminal behavior does not logically differ from legal behavior (e.g. Voss and Abraham 2000: 72). Such an action theoretical approach, which belongs to the family of rational choice theories, is capable of explaining and empirically describing every social action as well as everyday behavior (e.g. Esser 1999).

Based on these considerations and, in particular, the view of the relationship between social class and criminality, this article pursues two aims. First, Becker's (1968) economic model is extended by the theory of subjectively expected utility (SEU). From the sociological perspective, it is theoretically insufficient to argue that criminality is primarily an individual problem. In particular, Becker's model neglects social factors such as incentives in different social situations or socio-structurally varying opportunities (Birbeck and LaFree 1993; Piliavin et al. 1986). Second, in order to fathom its workability, the empirical findings of the extended SEU model for the explanation of shoplifting and tax evasion is employed. There are insufficient empirical applications of such models as the 'rational action theory', which aim at a sociological in depth explanation of criminal behavior (e.g. Cornish and Clarke 1987; Curti 1998; Grasmick and Bursik 1990; Homel 1983; Paternoster 1989; Piliavin et al. 1986). ${ }^{4}$

\section{Theoretical Discussion}

Criminality within society is the aggregated consequence of criminal behavior in various social conditions. It is the manifestation of this conscious behavior, and the produced deviations contrary to convention, which culminates in the violation of the criminal law code. Logically, due to this act of violation, miscreants resort to concealing their behavior. In order to understand the relationship between social structure and criminality, the socio-structurally differing delinquency of individuals acting on the micro level requires further analysis. 


\section{Becker's (1968) Basic Model}

According to Becker (1968), a (sane) person commits an offence if the subjectively expected benefit outweighs the advantages possibly realized (through utilizing time and additional resources in other activities). Consequently, individuals do not become 'criminals' because they differ from other people in terms of their basic motivation but because their benefits and costs are different (Becker 1968). Thus, an actor chooses legal or illegal actions, which he subjectively expects to increase his benefit (Cornish and Clarke 1987: 933), hence satisfying his needs, even though particularities (such as the desire to kill) are morally unthinkable (Curti 1998: 27). ${ }^{5}$

Apart from the benefit ' $B$ ', we employ the abbreviation advocated by Becker (1968), in which a person expects from his offence both the subjectively expected probability 'p' of apprehension, as well as the costs ' $C$ ' for the subjectively expected level of penalty, which has to be considered in a person's decision favoring or opposing a criminal act. Thus, the economic theory of crime evades the otherwise common assumptions in sociological approaches that individuals only follow a dominant strategy of acting; for example, that they principally act criminally due to their socialization or owing to a lack of self-control (McCarthy 2002: 437). ${ }^{6}$ According to Becker (1968: n17), the expected utility 'EU' for the offence 'O' can be defined as: $E U[O]=B-p C$.

Hypothesis 1: An offence is committed if the expected utility is greater than the expected costs that result from detention and penalization: $B>p C$.

Since the probability is no exogenous quantity but a subjective expectation of individuals, the assumption is that it varies between the social classes. Cornish and Clarke (1987: 935) point out that in the rational choice perspective, the choice of an (illegal) action alternative is determined exactly by the varying assessments of utility, costs and risks by different potential offenders. Rather than assume that potential offenders are fueled by a general disposition to offend, which makes them relatively indifferent to the nature of the offense they commit, the rational choice perspective asserts that specific crimes are chosen and committed for specific reasons.

Decisions to transgress are influenced by the characteristics of the offenders and the nature of the transgression. The differing in assess- 
ment between the social classes is explained by the existing knowledge differences regarding the solving of particular offences. Thus, an individual's erroneous estimation of the (controlling) authorities' workings and successes may evoke an under- or overestimation regarding the probabilities of capture. ${ }^{7}$ The working class, for example, when contrasted to the middle and upper classes, overestimate the probability of apprehension by the revenue authorities in the case of tax fraud. Personal experiences or differential associations might also contribute to the formation of subjective expectations of apprehension in an offence. Frequently associating with successful bank robbers would entice an individual to assume a low probability of conviction amongst bank robbers.

Hypothesis 2: It is presumed that:

1. Individuals from lower social classes overestimate the probability of capture for offences typically regarded as 'white collar crimes' (e.g. tax evasion).

2. Individuals from higher social standings, however, overestimate the probability of capture for offences assigned to 'blue collar crimes' (e.g. car theft).

The penalization of a solved offence is now nothing more than the price of the criminal behavior to which the opportunity and transaction costs have to be added. ${ }^{8}$ Thus, a severe penalty for criminal behavior is supposed to deter acts of criminality. Since the degrees of penalty for various offences are often unknown, the subjective assessment of the sentence is contaminated with inaccuracies and uncertainties, and shows a broad variety of expected penalties. Measured by the objective rationality, these subjective assessments are often objectively wrong, due to individuals' bounded rationality (Cornish and Clarke 1987; Simon 1993).

It must be assumed that due to their knowledge of the laws and possibly on account of having personally experienced prosecution by the revenue authorities, members of the middle or upper class are able to assess precisely the penalties meted out for tax evasion, while tax payers from the working or lower classes systematically overrate the degree of penalty for tax fraud. ${ }^{9}$ Since tax evasion is, (normally), castigated with high fines, the income situation of the lower social classes implies that they associate the implication of tax fraud with such high retribution costs, that they can hardly amortize them. Individuals from high-income social classes 'prefer' 
these offences since fines appear to be lighter penalties than lengthy prison sentences. From their perspective, the opportunity costs resulting from custody are higher than the fines normally imposed (for details see also Becker 1968).

Hypothesis 3: The existing variation - concerning information, knowledge and experiences - between the social classes yields class-specific expectations regarding the degrees of penalty for criminal offences. Unlike higher social classes, individuals from lower social classes tend to miscalculate the severity of offences sanctioned by (high) fines (and which are typically assigned to white-collar criminality).

\section{Extension by Use of the Theory of Subjectively Expected Utility}

In reality, severe penalties, per se, do not appear to act as a deterrent. Some societies avenge warranted offences with the death penalty, which, however, constantly fails to act as a deterrent. Thus, there have to be other determinants of criminal behavior apart from the expected and assessed degree of penalty. In view of this, one could argue with pathologies, personality traits (e.g. Gottfredson and Hirschi 1990), or heredity. However, the rational choice approach shows that criminal actors differ from law-abiding ones in evaluating similar incentives differently.

The subjectively expected utility ' $B$ ' is an important incentive, which, from an individual's perspective, results from criminal behavior. ${ }^{10}$ It can comprise scarce and desirable goods, such as income legally acquired, or lead to the improvement of one's own personal situation, e.g. murder of an annoying spouse. Besides class affiliation, incentives and opportunities play a decisive role. Thus, tax payers from the working and lower classes expect a lower utility from tax evasion than those from higher social standings since - due to their lower income and the expected low benefits - they (unlike those with a higher income) hardly gain advantage from a tax fraud. Consequently, it is the characteristics of an offence that make it appear attractive for certain individuals or groups, and which determine the action choice (Cornish and Clarke 1987: 935).

Hypothesis 4: The higher the assessment of the subjectively expected utility of the criminal action, the more probable is its manifestation. However, the subjectively expected utility interacts 
with the incentives, which from the individual's perspective are associated with his socio-economic situation. Since the special incentives vary among the social classes, there is a relationship between social class and certain kinds of offences, which are referred to in criminal-sociological typologies as 'white-collar' and 'blue-collar' criminality.

However, the decisive factor for the realization of the utility is not whether witnesses report the deed, or the intermediate control authorities revealing the offence, but whether an individual sees $\mathrm{him} /$ herself in the position of successfully carrying out a certain offence. On the one hand, the actor needs knowledge of whether the plan leads to the goal and how the plan itself is to be accomplished. However, objective knowledge alone is insufficient but a person must be certain to be in the position to carry out a criminal action. He or she must dispose of the control expectations and the control beliefs (e.g. Heckhausen and Schulz 1993). ${ }^{11}$

As already mentioned, they correspond, on the other hand, with socially differential contacts and the socially conveyed access chances to illegitimate means. Initially, it appears implausible that only those liable for taxation and equipped with the necessary knowledge, can betray the tax office with a fictitious tax return; and stereotypically, one can only raid a bank with a certain knowledge about robbery, equipped with weapons and a getaway car (Opp 1989: 410). The triviality of this argumentation recedes upon integration with the existing social conditions and its subjective definition.

Hypothesis 5: There exists a relationship between certain offences and social class because the opportunities for those offences correspond with the social class. So the direction and strength of the relationship between the social classes and delinquency depends on a society's opportunity structure for criminal behavior. The opportunity structure either fosters specifically 'blue-collar' or 'white-collar' criminality so that there is no relationship between social class and criminality if there is no distinction between different offences.

From the Theory of Subjective Expected Utility perspective, opportunities which influence the decision making process (as subjective factors) determine an individual assessment of the probability 
of success ' $q$ ' that the advantage of an offence can be realized. This probability of success is independent from the probability of being caught. The expected utility of an offence is weighted with this probability of success. Thus Becker's (1968) economic model can be extended and formalized in the following way: $S E U[O]=q B-p C$, in which $\mathrm{SEU}[\mathrm{O}]$ is the subjectively expected utility from the offence $O, q$ the expected probability of successfully carrying out the deed, $B$ the value of the expected utility, $p$ the probability of being caught and $C$ the expected degree of penalty. An offence $O$ is carried out if: $q B>p C$, and remains undone if: $q B \leq p C$.

Hence, four variables are identified through which criminal behavior can be explained: (1) the utility from the deed; (2) the degree of penalty; (3) the probabilities of realizing the utility through the deed; and (4) capture (and conviction). Differences in criminal behavior between classes are the result of different, class-related assessments of these four variables. Additionally, this equation clearly points to individuals who are capable of acting successfully $(q=1)$, and who consider the importance of the probability of being caught and punished $p$. It can be between 0 (the person is certain of not being caught) and 1 (the person expects to be convicted). If the actor assumes the extreme case $p=0$, the expected utility $S E U[O]=B$ still remains and already a very low utility provides an incentive for a deed. If the person assumes a value of $p=1$, the utility function consists of the difference between costs and utility: $S E U[O]=B-C$. If the value of $B$ exceeds $C$, the deed is committed despite certain punishment.

Thus, it appears that committing an offence can also be rational with a high risk without the urgent necessity of appealing to psychological constructs such as an existing attitude towards risk (willingness or reluctance to take a risk or risk neutrality) for its explanation. However, if risks and sanctions are considered irrelevant, the motivation for criminal behavior is, apart from the utilities, determined by one's own ability to commit an offence more or less successfully, i.e. the existing 'criminal energy'.

Hypothesis 6: There exists a relationship between the subjectively expected utility and the choice of a particular criminal action. The assessment of utilities differs among the social classes but is linked to the set of possible offences considered before. Thus, individuals from the middle and upper class are more likely to 
commit tax evasion since, unlike the lower social classes, they are convinced of success.

The economic approach regarding the explanation of criminal behavior (Becker 1968; McKenzie and Tullock 1984) is restricted to maximizing a problem under risk, without considering sociological dimensions of subjective perception and assessment of action determinants. Thus, norms and their internalization are irrelevant to them for the probability of criminal behavior. However, the SEU theory is decisive on how an individual's social situation is defined and which action alternatives can actually be taken into consideration. Categorical norms internalized by the individual, such as the 'golden rule' or 'always obey the laws, regardless of whether you agree to them' constitute action restrictions (since they pose a restriction in this initial cognitive phase of the decision making process of the set of possible and considered action alternatives). They are part of the 'framing', which precedes the actual decision making process and integrates it into the respective cognitive frames and the appropriate knowledge stocks, beliefs, attitudes and values (e.g. Esser 1996b). ${ }^{12}$ Thus, individuals prefer, or better perceive, such stimuli that agree with the values, beliefs and attitudes stored in their memories.

On the other hand, information which collides with existing values and beliefs encounters objection from the psyche and is either ignored or reinterpreted. Apart from the limited capacities to absorb information, this constitutes a further restriction of selective information processing. ${ }^{13}$ According to the theory of differential association, however, the adulteration of the validity of social norms occurs through correspondent learning processes. If one operates in groups which regard tax fraud as a self-evident and popular behavior, or where resistance against laws or civil disorder is considered socially obligatory, such norms become increasingly irrelevant as perception filters and assessment factors for opportunities of law-abiding behavior. Demands of reference groups and the liability of internalized norms can (in the example of shoplifting as a required initiation ritual into peer groups) accordingly evoke individual conflicts, which complicate and prolong the process of evaluation and decision making. ${ }^{14}$ 'It is particularly the reference groups of the everyday environment which bestow the necessary reference frame upon the individual's behavior thus, finally, filling the extended requirements of opportunities and institutional rules, 
the valid social interests and cultural ideas with sense, energy and life' (Esser 1999: 461, our translation). It is not only the action alternatives that are influenced by the affiliation to a group, but access to, respectively, legitimate or illegitimate possibilities that further influences the subjectively expected probability of success regarding the offence. For 'socialized' individuals, the choice between conformity and criminality does not constitute a real problem, but it is a routine reaction to particular stimuli with concurring behaviors (Wittig 1993: 115). Bachman et al. (1992: 367) conducted a survey among male college students about hypothetical sexual assault and conclude: 'We found that when the male's behavior in the scenario was thought to be morally wrong, our respondents were unaffected by instrumental concerns of cost/benefit. Their moral condemnation of the action was so strong that they could not even consider the possibility of offending' (see also Paternoster 1989; Tyler 1997: $222-3) .^{15}$

Hypothesis 7: The more strongly a person is integrated into the normative structure of his reference group which judges conformity to the law as positive, and the more strongly he adheres to this compliancy and the more likely he finds assurance in it, the lower is the probability of his choosing criminal actions.

\section{Interim Conclusion}

Let us summarize our theoretical outlines: The crime rate in a given society is conceived as a non-intended byproduct of independent rational - action - decisions of individual actors (see Figure 1). The decision for or against a criminal offence depends on processes and mechanisms of rational choice and is therefore a special case of the general theory of rational choice. Socially defined aims and the distribution of means, considered as macro level legitimacy, are perceived and interpreted dependent on a person's socioeconomic status (see Friedrichs 1997: 473). Special incentives, opportunity structures, individual resources, and liaison with social reference groups correlating to a person's social class are the determined considerations to action alternatives (Opp 1989: 410). The inclination towards criminal behavior occurs when a person is convinced of attaining desired products, or of establishing profitable events, in a manner contrary to law-abiding behavior. 


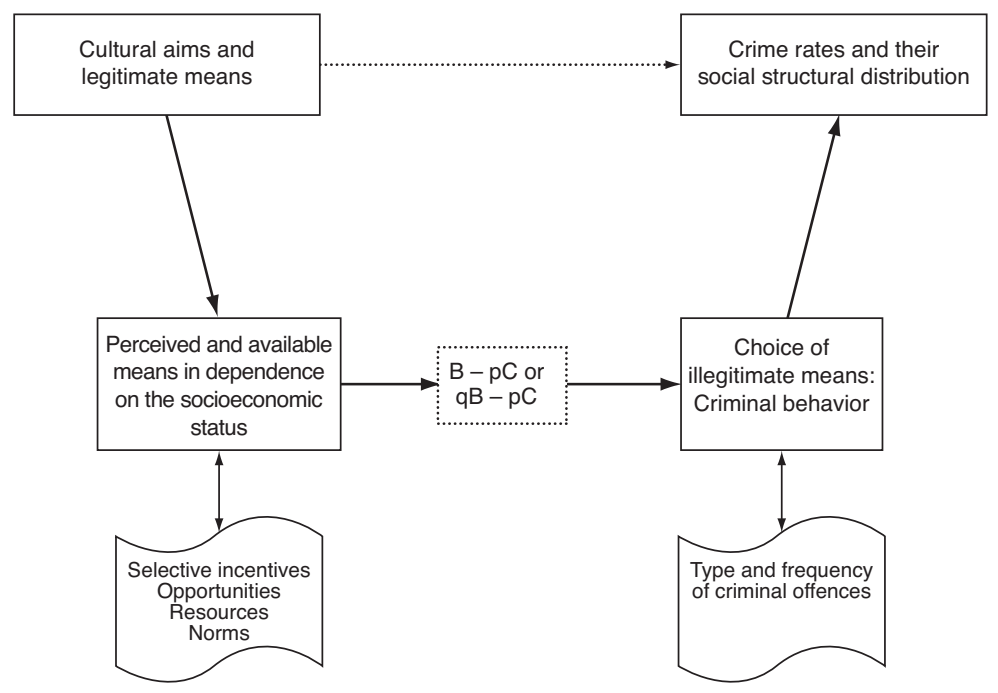

Figure 1. Social Structure and Criminality as an Aggregated Consequence of Delinquent Behavior

The social-structural variation of the subjectively assessed action alternatives results in a class-specific distribution of the considered offences. If evaluation of the offence exhibits an efficient alternative when compared to law-abiding actions, execution of the offence manifests, unless sanctions connected with the revealed offence are prohibitive. Apart from the subjective assessment of capture, the subjective expectation of being able to execute the offence successfully is a decisive factor, too. Both the subjective assessment of utilities and penalties connected with the offence, and the subjective assessment of the probability of success and punishment, vary among the social classes and yield the class-differing distribution of particular criminal actions (Opp 1989: 411).

The aggregation of an individual's illegal actions indicates too, in relation to law-abiding behavior, the explanation of the crime rate. According to the theoretical background of methodological individualism, it must be assumed that, due to undifferentiated aggregation rules, the findings about the negative relationship between social class and criminality, which have been presented to society at large, are of low expressiveness as long as there is no distinction between the individual types of offences. With this distinction, it 
becomes clear, in view of the presented model, why people from the middle and upper classes are more likely to commit tax evasion than those from the working and lower classes. Moreover, it should be comprehensible why the middle and upper classes as actors are hardly interested in bank raids.

The economic model of criminal behavior proposed by Becker (1968) is complete at the action-theoretical level. On the one hand the subjective probability of success was, in addition to the subjectively expected probability of being caught and punished, explicitly introduced as an additional determinant of the individual process of evaluation and decision making, which is independent from the subjective probability of being convicted of the criminal offence. Furthermore, an attempt was made to make the economic model more realistic by employing the sociologically founded distribution of different incentives and opportunity structures. This attempt at realism was successfully conducted by systematically integrating constituents taken from the anomie theory by Merton (1968), the theory of differential association by Sutherland and Cressey (1966), and finally, the theory of opportunity structures by Cloward (1968). Finally, the mediation and the learning of norms, i.e. the subjective evaluation of justice and injustice, as well as the obligation towards the law or the authorities in general (e.g. Tyler 1997: 223), in previous socialization processes, were included as a frame into the SEU model, which although an important definition of one's social situation and subsequent behavior, remains unconsidered in Becker's (1968) economic theory.

\section{Data, Variables and Statistical Methods}

\section{Data Basis}

Since criminality as a social phenomenon is the aggregated consequence of intentional individual behavior, it requires a micro-analytic analysis of an actor's delinquent behavior in order to appreciate the cause and reasons of this phenomenon, as well as the effects and consequences of delinquent behavior. Such micro processes are analyzed using individual data since inquiry with data on the macro level produces false conclusions (Pilivan et al. 1986: 102). Thus, the data from the German General Population Survey (ALLBUS) 
for the years 1990 and 2000 was employed for the empirical analysis (e.g. Koch et al. 2001; Wasmer et al. 1991). ${ }^{16}$ In the year 1990, 3051 German citizens of mature age and residing in private households in the Federal Republic were interviewed. The random sample of the ALLBUS 2000 includes 3138 German-speaking people residing in private households.

'Sanction and deviant behavior', a main subject of the ALLBUS 1990, was partly replicated in the ALLBUS 2000. ${ }^{17}$ In order to avoid a refusal of answer on a larger scale, merely minor offences were discussed. Thus, people were asked in both studies whether and how often they had committed offences such as tax evasion, shoplifting, fare dodging or driving while intoxicated, and if they would commit these offences in the future. Furthermore, those asked were not only supposed to assess these offences morally but also to subjectively evaluate the probability of being caught committing such offences. Exclusively in the ALLBUS 1990 people were asked about the degree of penalty for offences like tax evasion or shoplifting and if they would be prepared to report these offences. Since it is only possible to extensively test the action-theoretical model of criminal behavior using this additional information, the multivariate analysis is restricted to the year 1990 .

The gathering of reliable and valid data on delinquency constitutes a methodical difficulty in population surveys due to either a refusal to answer or inaccurate information given regarding one's own delinquent behavior (Hindelang et al. 1979). Biased samples, with regard to criminal behavior, also result from the fact that detained offenders remain unreachable in population surveys. There are good reasons why interviews guaranteeing anonymity hardly bring forth systematic false statements (e.g. Esser 1986). Undeniably, there exists the likelihood that convicted citizens are likely to conceal their offences, and that a law-abiding person, in accordance with norm-deviating reference groups, will mention offences which he had never committed (Diekmann 1980: 48-9). In order to minimize systematic losses owing to delicate questions about delinquent behavior, the ALLBUS 1990 and 2000 preserved the interviewees' anonymity by application of the 'sealed-envelope technique'. Those queried had a choice of answering questions on delinquency in writing and submitting their answers to the interviewer in a sealed envelope (Becker and Günther 2004; Sudman and Bradburn 1974; Sudman et al. 1996). ${ }^{18}$ 
Although the ALLBUS studies comprise relevant information about delinquent behavior on the individual level, their crosssectional character involves further methodical difficulty. If the inclination towards criminal behavior is independent of exogenous factors but dependent upon subjective assessments of (1) utilities, (2) costs and (3) probability of capture, it has to be taken into account that such subjective expectations and assessments change over the years (e.g. Curti 1998: 34; Davis 1988). Consequently, prospective longitudinal data would be the ideal basis of analysis (Blossfeld 1996; Niggli 1994: 96). To the best of our knowledge, such data is not available. Since the intention towards criminal behavior was recorded prospectively in the ALLBUS, its causes and restrictions can be adulterated by applying the cross-sectional analysis of the ALLBUS (Palivin et al. 1986: 103). However, the problem regarding the intentions towards delinquent behavior, as well as the expectations and assessments relevant to this type of behavior, are dependent upon (1) the situational context and (2) if the situation remains unsolved (e.g. Esser 1999; Niggli 1994: 93). Hence, cross-sectional surveys can involve some errors in measurement, whose extent and consequences are empirically unknown for analysis. With reference to delinquent behavior, methodology reservations regarding the ALLBUS data are plausible, yet empirically unsecured.

\section{Dependent and Independent Variables}

The readiness to commit a criminal offence constitutes the dependent variable. The interviewees were asked whether they foresaw themselves recommitting an offence (once again), or abstaining from repeating such illicit acts, regardless of the circumstances. The first consideration is tax evasion ('Giving misleading data in the tax declaration or the manipulation of income tax in order to pay fewer taxes') and the other shoplifting in a department store ('Taking goods out of a department store or shop without paying'). Prior to the inquiry regarding their prospective behavior, interviewees were also asked if they had committed the mentioned offences before, and if so, how often an occurrence. Both offences were analyzed separately. We use intended (future) criminal offence as the dependent variable, and not prior offences. Our theoretical model predicts that the cognition of the situation is crucial for the individuals' assessment of costs, benefits, certainty of sanctions 
and so on. These potential predictors of crime do not necessarily remain constant over time, hence, if we choose prior offences as the dependent variable we would have to record the situational circumstances, the expected costs, benefits and probability of the time for the offences to actually happen. Therefore, the respondents would have to recall the necessary details of the past circumstances, an arduous and impractical task (see Dillman 2000: 37). Instead, we choose the intended behavior and assume that the respondents will answer this question in accordance with their present interpretation of their situation. Pogarsky (2004: 111-12) briefly summarizes: 'Retrospective measures have the advantage of being based on actual crime, but do not test the instantaneous relationship between criminal behavior and potential predictors. Prospective measures permit instantaneous test, but assume individuals' projected and actual behaviors correspond'. In an experimental design, Pogarsky (2004) found a positive correlation between intended offending and contemporaneous rule-violation. ${ }^{19}$

The arguments therefore state that shoplifting and tax fraud are trivial bagatelle offences, and that it would be better to analyze an offence comparable for all classes, i.e. an offence which varies independently from social standing (which may not be the case for these two offences). The rebuttal to the argument states that: (1) the choice of the offences is dictated by the available data source, and (2) there exists no offence that is independent of social standing. It will be shown that criminal behavior is distributed relatively ubiquitously in society. In other words, there exists no social class, which registers a higher quota of offenders. The types of offences, however, greatly vary amongst the classes.

The ALLBUS also measured the subjective utilities, costs and assessments of the probabilities of success and being caught, as well as the sanctions, as demanded by Opp (1989: 426). Thus, the subjectively expected probability of being caught $p$ constitutes an important independent variable in the economic model (see Paternoster et al. 1982: 1255). Those asked were to rate on a fivestage scale from 'very likely' to 'very unlikely' the subjective probability of being caught stealing, or that the tax office will discover the offence. ${ }^{20}$ For the multivariate analysis, the nominal data were transformed into probability data in percentages. For the extended SEU model, the probability of being caught $p$ was measured in a different way. This resulted from technical reasons since in the evaluations of the SEU model the complement to the variable for 
the probability of being caught has to act as probability of success $q$. Thus, the interviewees were to give the probability of reporting on another person's tax evasion. Approximately, the probability of penalty $p$ can be measured through this preparedness to report, provided that the person queried also considers this assessment as valid regarding his or her own tax fraud (Diekmann 1980: 37). A similar approach was employed for shoplifting, where it was measured how highly the interviewees esteem a thief's punishment. The (possible) answers were each transformed into probabilities of their percentages, respectively. The probability of success $q$, is, contrary to Becker (1968), not defined as the complement to the probability of being caught but as an independent value defining action competence. Due to the lack of an alternative measurement in the ALLBUS, it is only possible to methodically use the counterprobability to the probability of being caught.

The subjectively expected costs of offences are displayed indirectly through the respondent's favored severity of sanction $C$ for the corresponding offences. Those queried were to state whether offences like tax evasion or shoplifting should be punished. Regarding the possible degree of penalty, it was to be distinguished gradually between diverse fines and imprisonment. Due to an extremely skewed distribution in the named penalties of shoplifting, the analyses disregard the degree of the severity of sanctions, by differentiating whether the offence was punishable. This non-normal distribution for the punishment of shoplifting may derive from the fact that, due to the triviality of this offence, there are no sanctions or they are less severe in nature. However, regarding the degree of penalty for tax evasion, the original scale was employed, thereby placing the penalties into the order of their degree. ${ }^{21}$ Due to the splitting of the data, which occurred during acquisition, the extended model for shoplifting is empirically assessable only if, instead of the degree of punishment, we utilize the subjective assessment in determining whether severe punishment deters criminal behavior.

The subjectively expected utility $B$ of an offence like tax evasion or shoplifting could be measured only indirectly, i.e. through behavior assessment, since the ALLBUS did not consider a direct measurement of an expected benefit from an offence. This moral assessment of delinquent behavior 'can ascertain whether a certain conduct norm is actually prevalent among the population or among particular subpopulations, in other words, whether certain behavior is actually classified as deviating' (Wasmer et al. 1991: 25, our translation). 
One can assume, however, that this normative deviation is connected with the expected benefits derived from this offence (Diekmann 1980: 86). Therefore, the empirical analysis of shoplifting differentiates whether this offence is assessed positively rather than negatively. The offence's negative assessment constitutes the reference category of these dummy variables. Since, in contrast to shoplifting, the degree of penalty for tax evasion was captured in a differentiated way, the expected utility from a tax evasion is measured in its original form.

The liability of internalized norms is assessed by the interviewees' compliance with the opinion 'Laws must always be obeyed regardless of one's agreement to them' (our translation). This variable measures the law obedience, which constitutes both an incentive for compliant behavior and a cognitive component of framing.

The queried person's monthly net income was considered as an opportunity structure for tax evasion and as an indicator for the selectivity of tax fraud since the level of income can constitute a special appeal to evade taxes. Regarding shoplifting, the magnitude of the political community portrays an indicator for opportunities, since an increasing community size also yields an increasing probability of anonymous and large department stores (Friedrichs 1997: 493-4).

Finally, regarding the relationship between social-economic status and delinquency, class affiliation is examined to determine the interviewees' subjective class grading which is distinguished between the upper class (mostly consisting of the upper middle classes, and constituting the reference category), the middle classes and finally the lower or working classes. At an earlier stage, the examination of class affiliation was based on objective criteria, which produced similar results as the subjective self-grading.

\section{Statistical Method}

The evaluation of a single determinant's influence on the intention of committing an offence is determined by the binary logistic regression. This method is employed for distribution-theoretical reasons as well as for decision-theoretical reasons (Urban 1993: 108). Hence, the intended offence can be described with a decision and action theoretical approach of the subjectively expected utility and the cost-benefit evaluation of action alternatives. As an example, a probabilistic action model for the process of a criminal action can 


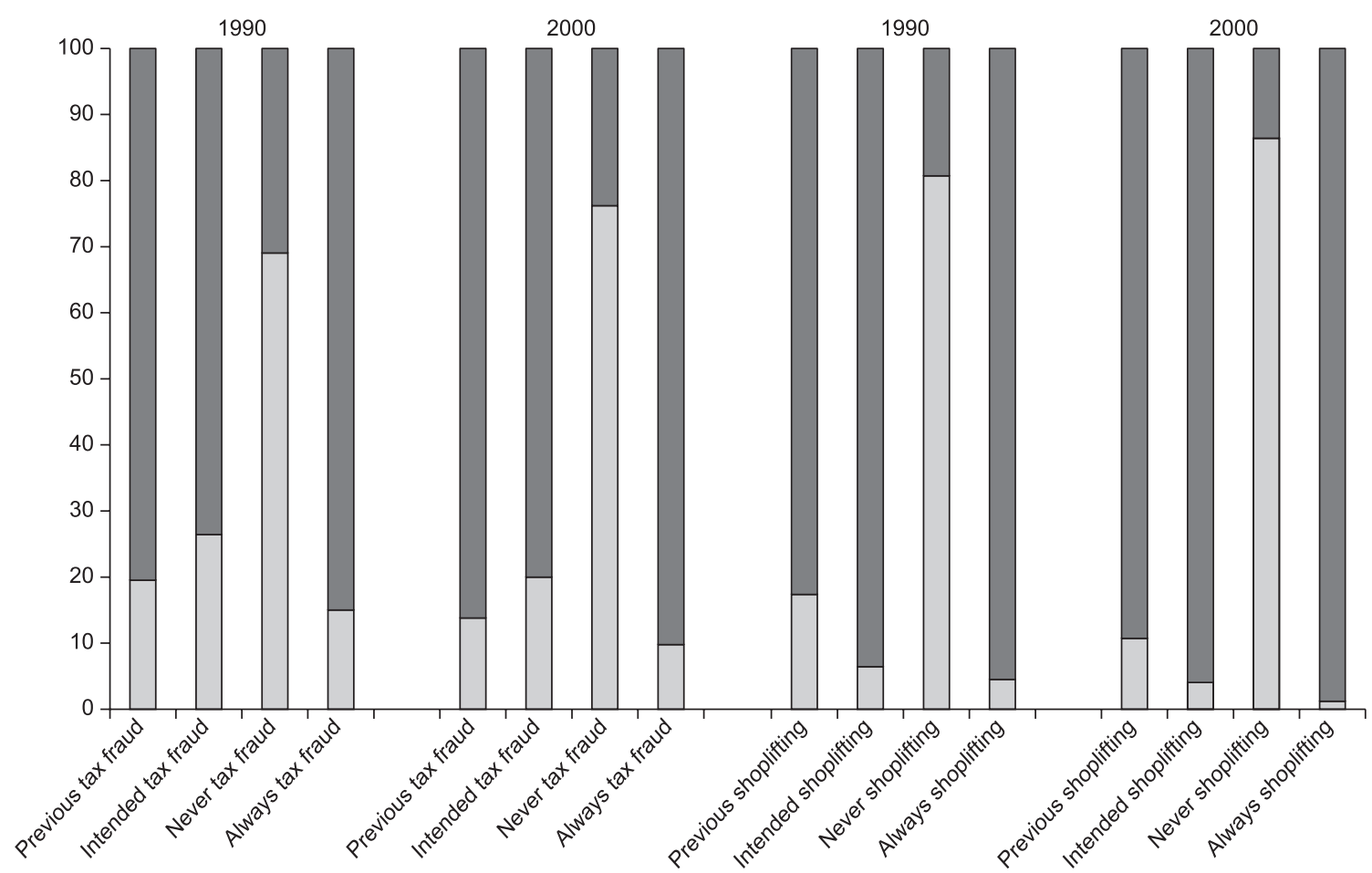

Figure 2. Comparison between Previous and Intended Delinquent Behavior - the Example of Tax Fraud and Shoplifting in the years 1990 and 2000 
be combined with and examined by the logic and statistic of logistic regression models (Urban 1993: 119).

\section{Empirical Results}

\section{Descriptive Findings}

Almost 20 percent of those queried in 1990 (14 percent in the year 2000) had already evaded taxes. Approximately 27 percent (20 percent) intend to commit a tax fraud (see Figure 2). Of the interviewees, 69 percent (76 percent) had never considered tax evasion and merely 15 percent (10 percent) had already evaded taxes and would do so, again, in the future.

Approximately 17 percent (12 percent) of those queried in the year 1990 (2000) stated that they had already committed shoplifting, whereas 7 percent (4 percent) contemplated such an offence. About 81 percent ( 86 percent) had neither stolen in the past nor would they commit shoplifting. Only a few of the respondents (5 percent or 1 percent, respectively) had already stolen and will repeatedly shoplift in a department store. ${ }^{22}$

As assumed, the lower social classes are far less likely to commit tax fraud than the higher classes (see Table 1). This result corresponds with the fifth hypothesis according to which the relationship between social stratification and opportunities constitutes an important reason for socially differing offences. Moreover, contrary to the daily hypotheses, there exists no relationship between class affiliation and intended shoplifting, not even when previous cases of shoplifting are considered (not documented here due to lack of space).

These findings are inconsistent with the sweeping results of previous studies, which is testimony to a negative relationship between one's socioeconomic status and the tendency to behave criminally. In particular, previous studies employing official aggregate data (unlike our approach) merely consider the percentage of members belonging to a certain class out of the known offender population, i.e. the social structural composition of the caught delinquents. Thus, apart from problems afflicted with socially selective undetected cases, the respective number of law-abiding individuals from the different social classes is excluded from consideration. ${ }^{23}$ 
Table 1. Intended Breach of Law Dependent on Class Affiliation Tax Evasion and Shoplifting

\begin{tabular}{lcccc}
\hline Offence & Tax fraud & Tax fraud & Shoplifting & Shoplifting \\
\cline { 2 - 5 } & 1990 & 2000 & 1990 & 2000 \\
\hline Constant & $-0.693^{* * *}$ & $-0.764^{* * *}$ & $-2.535^{* * *}$ & $-3.632^{* * *}$ \\
& $(0.191)$ & $(0.229)$ & $(0.288)$ & $(0.579)$ \\
Class affiliation & & & & \\
$\quad$ Reference: upper class) & & & & \\
Lower and working class & $-0.501^{*}$ & $-0.906^{*}$ & 0.176 & 0.703 \\
\multicolumn{1}{c}{ Middle class } & $(0.233)$ & $(0.277)$ & $(0.334)$ & $(0.622)$ \\
& -0.179 & -0.403 & 0.069 & 0.452 \\
Pseudo- $R^{2}$ (McFadden) & $(0.211)$ & $(0.251)$ & $(0.315)$ & $(0.612)$ \\
$N$ & 0.005 & 0.012 & 0.001 & 0.004 \\
& 1230 & 932 & 1447 & 1195 \\
\hline
\end{tabular}

Notes: Logistic regression (in brackets: standard error of coefficient); ${ }^{*} p \leq 0.05 ; * *$ $p \leq 0.01 ; * * * \leq 0.001$.

Source: ALLBUS 1990 and 2000 (weighted) - own calculations.

It has to be mentioned that official aggregate data (criminal statistics derived in part from the police department) merely comprise caught offenders (including wrongly suspected, but innocent, individuals). Individual statistics like the ALLBUS, in contrast, also include undetected cases. Thus, according to our data, the population of defrauders, for the most part, consists of individuals from the middle class and mainly the upper class, as already expected. Merely by considering a group of delinquents' composition for shoplifting, one is aware of an overrepresentation of offenders from lower social classes. In official data, these shoplifters are represented disproportionately since they are more likely to be caught. The indication from our data states that the often proclaimed negative relationship between social class and delinquency is a 'myth' (Dunaway et al. 2000; Tittle et al. 1978). Our findings, however, clearly reveal the fact that there are obviously certain offences preferably committed by individuals from certain social classes. The theoretical reasons given for this have now to be tested empirically. 


\section{Empirical Tests of the Basic Models}

Measured by the determinants of intended tax fraud and shoplifting, Becker's (1968) economic model can be regarded as empirically verified (see hypothesis 1 as well as Tables 2 and 3). ${ }^{24}$ If people place greater importance on the expected utility instead of the probability of being caught and the severity of the penalty, then, measured by the general tendency to commit tax fraud or shoplifting, many more people are prepared to evade taxes.

Unlike tax fraud, shoplifting does not appear to belong to 'mass delinquency'. Thus, 7.9 percent of all interviewees would shoplift, compared with 21 percent of those who expect benefits rather than disadvantages from a theft, which is a strong indication of shoplifting being chosen as an action. The perceived probability of being caught and punished obviously prevents many of the actors from stealing even if they associate shoplifting with a comparatively high benefit.

Table 2. Probability of Tax Fraud Dependent on the Utility $B$, Probability of Being Caught $p$ and Degree of Penalty $C$ (row percentages)

\begin{tabular}{lcc}
\hline & $\begin{array}{c}\text { No tax evasion } \\
(\%)\end{array}$ & $\begin{array}{c}\text { Intended tax evasion } \\
(\%)\end{array}$ \\
\hline$B \leq p \cdot C$ & 73 & 27 \\
$B>p \cdot C$ & 58 & 42 \\
Total & 69 & 31 \\
\hline
\end{tabular}

Note: $\mathrm{Phi}=0.146(p \leq 0.001)$.

Source: ALLBUS 1990 - own calculations.

Table 3. Probability of Shoplifting Dependent on the Utility $B$, Probability of Being Caught $p$ and Degree of Penalty $C$ (row percentages)

\begin{tabular}{lcc}
\hline & $\begin{array}{c}\text { No shoplifting } \\
(\%)\end{array}$ & $\begin{array}{c}\text { Intended Shoplifting } \\
(\%)\end{array}$ \\
\hline$B \leq p \cdot C$ & 93 & 7 \\
$B>p \cdot C$ & 79 & 21 \\
Total & 92 & 8 \\
\hline
\end{tabular}

Note: $\mathrm{Phi}=0.136(p \leq 0.001)$.

Source: ALLBUS 1990 - own calculations. 
However, even after interpreting these findings, we have to consider the influences of different incentives and opportunities for shoplifting, which has remained unconsidered. Let us clarify this for tax fraud. While 31 percent of those asked would consider a tax fraud, only 42 percent of those who assess expected utilities higher than weighted costs would do so. Among the lower social classes merely 27 percent of the interviewees would evade taxes, but 36 percent see benefits rather than disadvantages. Among the middle and upper classes, between 45 and 47 percent of the taxpayers, respectively, would defraud the tax office if they anticipate benefits rather than disadvantages. An introduction of this bridge hypothesis into the economic model by Becker (1968) not only improves the prediction of criminal behavior in knowledge of subjective expectations and assessment of costs and utilities of criminal behavior but also makes the description of criminality's reasons and causes far more realistic.

The economic model of criminality by Becker (1968) is further endorsed by a multivariate assessment (Models 2 and 4 in Table 4). However, in contrast to Becker's general assumption, the expected degree of penalty does not have a significant influence on the intended tax fraud (Model 1). A possible reason could be that the severity of the penalty is unknown to most taxpayers. Considering the standardized effect coefficients, the estimated risk of being caught is then decisive (e.g. Tyler 1997: 220).

In the case of shoplifting, the degree of penalty exerts a relatively low, albeit significant influence on the tendency to steal (Model 3). People are deterred, once again, from stealing by the subjective expectation of being caught. This expectation, however, has only a minor influence on the decision for or against shoplifting. Due to a lack of information, the ALLBUS data cannot be employed to examine whether informal sanctions are more effective in preventing shoplifting. Generally, our findings contradict the concept of deterrence according to which the degree of penalty makes offences more unlikely. In the case of shoplifting, the expected utility dominates the deterrent effect of sanctions whereas in the event of tax fraud, the influences of expected advantages and disadvantages balance each other (Models 2 and 4).

These findings, which largely support the model by Becker (1968), are replicable by means of the theoretical model of subjectively expected utility (see Table 5). The degree of punishment is irrelevant for either tax fraud or shoplifting, whereas certain importance is 
Table 4. Determinants of Tax Fraud and Shoplifting - Becker's (1968) Model

\begin{tabular}{|c|c|c|c|c|}
\hline & \multicolumn{2}{|c|}{ Tax evasion } & \multicolumn{2}{|c|}{ Shoplifting } \\
\hline & Model 1 & Model 2 & Model 3 & Model 4 \\
\hline Constant & $\begin{array}{l}-1.421 * * * \\
(0.409)\end{array}$ & $\begin{array}{l}-2.045^{* * *} \\
(0.336)\end{array}$ & $\begin{array}{l}-1.978 * * * \\
(0.339)\end{array}$ & $\begin{array}{l}-2.709 * * * \\
(0.201)\end{array}$ \\
\hline Value of utility $B$ & $\begin{array}{l}0.687 \text { *** } \\
(0.121) \\
{[1.830]}\end{array}$ & $\begin{array}{l}0.650 \text { *** } \\
(0.113) \\
{[1.772]}\end{array}$ & $\begin{array}{l}1.485 * * * \\
(0.213) \\
{[1.980]}\end{array}$ & $\begin{array}{l}1.582 * * * \\
(0.202) \\
{[2.071]}\end{array}$ \\
\hline $\begin{array}{l}\text { Probability of being caught } \\
\quad p \text { (risk) }\end{array}$ & $\begin{array}{c}-0.021 * * * \\
(0.003) \\
{[1 / 1.953]}\end{array}$ & & $\begin{array}{c}-0.013 * * * \\
(0.003) \\
{[1 / 1.497]}\end{array}$ & \\
\hline Degree of penalty $C$ & $\begin{array}{c}-0.135 \\
(0.102) \\
{[1 / 1.151]}\end{array}$ & & $\begin{array}{c}-0.552 * \\
(0.274) \\
{[1 / 1.174]}\end{array}$ & \\
\hline Risk $p^{*}$ degree of penalty $C$ & & $\begin{array}{c}-0.007 * * * \\
(0.002) \\
{[1 / 1.771]}\end{array}$ & & $\begin{array}{c}-0.010 * * * \\
(0.003) \\
{[1 / 1.409]}\end{array}$ \\
\hline Pseudo-R ${ }^{2}$ (McFadden) & 0.141 & 0.105 & 0.106 & 0.105 \\
\hline$N$ & 667 & 667 & 1428 & 1428 \\
\hline Percentage of delinquents & 31.3 & 31.3 & 7.9 & 7.9 \\
\hline
\end{tabular}

Notes: Logistic regression (in round brackets: standard error of coefficients and in square brackets: standardized effect coefficients); $* x \leq 0.05 ; * * p \leq 0.01$; $* * * p \leq 0.001$.

Source: ALLBUS 1990 - own calculations.

attached to the expected benefit and the subjective probability that the offence will be punished (Model 1). The latter, however, is merely significant at the 10-percent level and becomes less important in the case of tax fraud if incentives and opportunity structures are examined (Models 1 and 2 as well as interaction terms).

On the one hand, it is ascertainable that the tendency towards tax fraud increases with the amount of the taxable net income (hypothesis 4) and that the intention to commit shoplifting becomes more likely with the community size (hypothesis 5). Different incentives and corresponding opportunities necessarily influence the choice of criminal actions. The internalized norm of implicit law obedience, on the other hand, prevents people from committing tax fraud or shoplifting (Model 2). 
Table 5. Determinants of Tax Fraud and Shoplifting - the SEU Model

\begin{tabular}{|c|c|c|c|c|c|c|}
\hline & \multicolumn{3}{|c|}{ Tax fraud } & \multicolumn{3}{|c|}{ Shoplifting } \\
\hline & Model 1 & Model 2 & Model 3 & Model 1 & Model 2 & Model 3 \\
\hline Constant & $\begin{array}{l}-3.383^{* * *} \\
(0.457)\end{array}$ & $\begin{array}{l}-3.083^{* * * *} \\
(0.541)\end{array}$ & $\begin{array}{l}-1.613^{* * *} \\
(0.303)\end{array}$ & $\begin{array}{l}-2.546^{* * *} \\
(0.378)\end{array}$ & $\begin{array}{l}-2.629 * * * \\
(0.559)\end{array}$ & $\begin{array}{l}-2.952 * * * \\
(0.189)\end{array}$ \\
\hline Value of utility $B$ & $\begin{array}{l}0.663 * * * \\
(0.126) \\
{[1.792]}\end{array}$ & $\begin{array}{l}0.637 \text { *** } \\
(0.131) \\
{[1.752]}\end{array}$ & & $\begin{array}{l}0.920 * * * \\
(0.248) \\
{[1.537]}\end{array}$ & $\begin{array}{c}0.632 * \\
(0.262) \\
{[1.344]}\end{array}$ & \\
\hline Probability of success $q$ & $\begin{array}{l}0.021 * * * \\
(0.003) \\
{[1.953]}\end{array}$ & $\begin{array}{l}0.021 \text { *** } \\
(0.003) \\
{[1.953]}\end{array}$ & & $\begin{array}{l}0.014 * * * \\
(0.004) \\
{[1.519]}\end{array}$ & $\begin{array}{l}0.013 * * \\
(0.004) \\
{[1.474]}\end{array}$ & \\
\hline Degree of penalty $C$ & $\begin{array}{c}-0.104 \\
(0.107) \\
{[1 / 1.114]}\end{array}$ & $\begin{array}{c}-0.089 \\
(0.109) \\
{[1 / 1.097]}\end{array}$ & & $\begin{array}{c}-0.321 \\
(0.252) \\
{[1 / 1.174]}\end{array}$ & $\begin{array}{c}-0.064 \\
(0.271) \\
{[1 / 1.033]}\end{array}$ & \\
\hline Probability of being punished $p$ & $\begin{array}{c}-0.007 \dagger \\
(0.004) \\
{[1 / 1.204]}\end{array}$ & $\begin{array}{c}-0.005 \\
(0.004) \\
{[1 / 1.142]}\end{array}$ & & $\begin{array}{c}-0.015^{* * *} \\
(0.004) \\
{[1 / 1.536]}\end{array}$ & $\begin{array}{c}-0.011 * * \\
(0.003) \\
{[1 / 1.370]}\end{array}$ & \\
\hline $\begin{array}{l}\text { Probability of success } q^{*} \\
\text { Utility } B\end{array}$ & & & $\begin{array}{l}0.009 * * * \\
(0.001) \\
{[2.452]}\end{array}$ & & & $\begin{array}{l}0.020 * * * \\
(0.004) \\
{[1.683]}\end{array}$ \\
\hline
\end{tabular}


Probability of being punished $p^{*}$ degree of penalty $C$

\section{Framing and selectivity}

Amount of net income

Community size

Pseudo- $R^{2}$ (McFadden)

$N$

Percentage of shoplifters

\section{Law obedience}

$$
\begin{gathered}
-0.004^{*} \\
(0.002) \\
{[1 / 1.286]}
\end{gathered}
$$

$-0.005 \dagger$

$(0.003)$

$[1 / 1.256]$

Notes: Logistic regression (in round brackets: standar

$* p \leq 0.05 ; * * p \leq 0.01 ; * * * \quad \leq \leq 0.001 ; \dagger p \leq 0.1$.

Source: ALLBUS 1990 - own calculations. 
As theoretically assumed by the seventh hypothesis, the preceding socialization obviously determines the 'framing' during the definition of the social situation and with it also the choice of the means in order to achieve certain social or individual aims. In our modified and extended model, social factors like education and acceptance of norms have an informal sanctioning character since the breach of such norms can also involve psychological costs (e.g. cognitive dissonance, impaired self-esteem and so forth). Internalized prosocial norms limit the set of alternative actions and exclude illegal ones. Additionally, the psychological costs of norm-violation are considered in advance. This also decreases the likelihood of delinquent behavior. ${ }^{25}$

In contrast to some other studies (i.e. Nagin and Paternoster 1993; Pogarsky 2004), we did not include prior offending as an independent variable into the equation to control for experiential effects. Prior offences affect future offences by altering the subjectively expected probability of either being caught or being successful, respectively. From the perspective of social learning theory compatible with rational choice (RC) theory (e.g. Bandura 2001), the outcome of the cognitive calculation depends on the success of prior offending. After committing a 'successful' crime, the actor will adjust his expected probability of detection and success. Conversely, if the committed crime has failed, the actor learns that he has to increase his estimated probability of being caught and/or to decrease the probability of success. Anyway, these experiential effects are captured by the RC variables.

Altogether, the theoretical model of expected utility proves to be workable in order to describe tax fraud and shoplifting extensively. Thus, individuals for whom probable benefits outweigh probable losses are more likely to consider an offence than individuals who fear sanctions are. Whereas 31 percent of the interviewees intend to evade taxes, 38 percent of those are prepared to do so if they expect advantages instead of disadvantages from tax fraud (see Table 6).

In other words, two-thirds of the tax defrauders are those individuals who expect advantages rather than disadvantages, whereas three-quarters of the 'honest' taxpayers are people who see advantages in law-abiding behavior. Measured by the general offence rate of shoplifting ( 6 percent), an exceptionally high percentage of 16 percent of individuals would steal if the expected benefits outweigh the probable losses (Table 7). Individuals who, in contrast, 
Table 6. Probability of Tax Fraud Dependent on Weighted Utility and Cost Terms (Row Percentages)

\begin{tabular}{lcc}
\hline & $\begin{array}{c}\text { No tax evasion } \\
(\%)\end{array}$ & $\begin{array}{c}\text { Intended tax evasion } \\
(\%)\end{array}$ \\
\hline$q \cdot B>p \cdot C$ & 91 & 9 \\
$q \cdot B \leq p \cdot C$ & 62 & 38 \\
Total & 69 & 31 \\
\hline
\end{tabular}

Note: $\mathrm{Phi}=0.269(p \leq 0.001)$.

Source: ALLBUS 1990 - own calculations.

expect sanctions rather than benefits, fit the imagery of an 'honest', law-abiding citizen.

This relationship becomes even clearer, if, in the case of tax fraud, the acceptance of social norms like implicit law obedience or class affiliation is examined. Merely 27 percent of all people sharing this norm, which is the majority out of 82 percent, would evade taxes. Among those who, additionally, expect benefits instead of sanctions, one-third would commit tax fraud. The rate of tax evasion among those who do not accept this norm can be well-predicted through the cost-utility considerations. Half of those people consider defrauding the tax office. If the feared sanctions outweigh the expected benefits, 6 percent of those people would not evade taxes. Otherwise, more than 58 percent of the citizens who expect advantages instead of disadvantages seriously consider tax fraud. If individuals from the working and middle classes do not share

Table 7. Probability of Shoplifting Dependent on Weighted Utility and Cost Terms (Row Percentages)

\begin{tabular}{lcc}
\hline & $\begin{array}{c}\text { No shoplifting } \\
(\%)\end{array}$ & $\begin{array}{c}\text { Intended shoplifting } \\
(\%)\end{array}$ \\
\hline$q \cdot B>p \cdot C$ & 96 & 4 \\
$q \cdot B \leq p \cdot C$ & 84 & 16 \\
Total & 94 & 6 \\
\hline
\end{tabular}

Note: Phi $=0.194(p \leq 0.001)$.

Source: ALLBUS 1990 - own calculations. 
implicit obedience to the law, they abstain from tax fraud entirely only if it appears to be an unworthy venture. Among the law-abiding individuals, the percentages of tax defrauders decrease in all social classes, remarkably below the general offence level for tax evasion, and even more so under the offence level for the few law abiding citizens, even if the benefits for tax fraud appear enticing. These findings elucidate the explanatory content of an in-depth explanation of the theory of expected utility if boundary conditions like incentives or opportunities, which are theoretically relevant to bridge hypotheses, are taken into account.

\section{Social Class and Delinquency}

In the following, we shall examine, individually, whether there exist theoretically assumed class-varying differences in the expectations and evaluations of tax fraud and shoplifting. As expected, the higher social classes are more likely to evade taxes since they expect a larger advantage than the working and lower classes (see Table 8). Merely one-quarter of the working class would evade taxes whereas almost one-third of the upper class considers tax fraud. Apart from the individuals' socioeconomic status, both incentives and existing opportunities constitute necessary conditions for the consideration of tax fraud in order to benefit from it (hypotheses 4 and 5).

The data in Table 8 confirm the sixth hypothesis according to which there are class-varying relationships between the subjective probability of success and the choice of a criminal action alternative. There is, however, no linear rise of this correlation in the social stratification. Thus, the influence of this factor is stronger among the working class than among the other social classes and therefore persists if individuals from the lower class are excluded from the analyses. Furthermore, the third hypothesis is unsustainable in the case of tax fraud since there exists no socially varying influence of the degree of penalty on the probability of evading taxes despite the weak, albeit significant, relationship between social class and the expected degree of penalty for tax evasion. Finally, the second hypothesis empirically verifies that the lower social classes assess the probability of being caught and punished for committing tax fraud as higher than those in the upper social classes. Among the middle and upper classes, this sanction probability exerts a relatively low influence on their decision since, due to direct and indirect 
Table 8. Determinants of Intended Tax Fraud Dependent on Social Class

\begin{tabular}{lccc}
\hline & Working class & Middle class & Upper class \\
\hline Constant & $-2.132^{* *}$ & $-2.567^{* * *}$ & $-4.127^{* * *}$ \\
& $(0.757)$ & $(0.489)$ & $(1.302)$ \\
Value of utility $B$ & 0.308 & $0.481^{* * *}$ & $1.112^{* * *}$ \\
& $(0.200)$ & $(0.123)$ & $(0.314)$ \\
Probability of success $q$ & $0.026^{* * *}$ & $0.019^{* * *}$ & $0.025^{* * *}$ \\
& $(0.005)$ & $(0.003)$ & $(0.008)$ \\
Degree of penalty $C$ & -0.139 & -0.026 & -0.197 \\
& $(0.168)$ & $(0.106)$ & $(0.243)$ \\
Probability of being punished $p$ & $-0.015^{*}$ & $-0.007 \dagger$ & -0.016 \\
& $(0.007)$ & $(0.004)$ & $(0.012)$ \\
Law obedience & $-1.246^{* * *}$ & $-0.684^{* *}$ & -0.632 \\
& $(0.373)$ & $(0.214)$ & $(0.515)$ \\
Pseudo- $R^{2}$ (McFadden) & 0.201 & 0.110 & 0.239 \\
$N$ & 294 & 730 & 146 \\
Percentage of tax defrauders & 24.5 & 26.8 & 31.5 \\
\hline
\end{tabular}

Notes: Logistic regression (in brackets: standard error of coefficients); ${ }^{*} p \leq 0.05$;

$* * p \leq 0.01 ; * * * p \leq 0.001 ; \dagger p \leq 0.1$.

Source: ALLBUS 1990 - own calculations.

experience, they know about the tax office being a rather unsuccessful control authority.

Additionally, they may have learnt to employ their own skills in order to keep the probability of being apprehended and punished as low as possible. Internalized law obedience prevents individuals from the working and middle classes from evading taxes, whereas the normative influence is more distinct amongst the working class than amongst the middle classes. Obeying laws is obviously easy if a contravention would yield none or little benefit, whereas even the best socialization remains fruitless if the benefits appear to be all-too enticing.

According to the fourth hypothesis, expected material benefits from shoplifting facilitate such an offence, and since, relatively speaking, individuals from lower classes can benefit more from that offence than individuals from the middle class, the expected utility among the lower classes has a stronger influence on the consideration of shoplifting (Model 1 in Table 9). Due to a lack of additional utilities, the upper classes do not appear to regard shoplifting 
Table 9. Determinants of Intended Shoplifting Dependent on Social Class

\begin{tabular}{|c|c|c|c|c|}
\hline & \multicolumn{2}{|c|}{ Working class } & \multicolumn{2}{|c|}{ Middle class } \\
\hline & Model 1 & Model 2 & Model 1 & Model 2 \\
\hline Constant & $\begin{array}{l}-2.830 * * * \\
(0.658)\end{array}$ & $\begin{array}{l}-1.944 * * * \\
(0.713)\end{array}$ & $\begin{array}{l}-2.371^{* * *} \\
(0.532)\end{array}$ & $\begin{array}{l}-1.736^{* * * *} \\
(0.589)\end{array}$ \\
\hline Value of utility $B$ & $\begin{array}{c}0.994 * \\
(0.455)\end{array}$ & $\begin{array}{c}0.692 \\
(0.486)\end{array}$ & $\begin{array}{c}0.680^{*} \\
(0.338)\end{array}$ & $\begin{array}{c}0.534 \\
(0.346)\end{array}$ \\
\hline Probability of success $q$ & $\begin{array}{l}0.021 * * \\
(0.007)\end{array}$ & $\begin{array}{l}0.018^{*} \\
(0.007)\end{array}$ & $\begin{array}{l}0.102 * \\
(0.050)\end{array}$ & $\begin{array}{c}0.096 \dagger \\
(0.055)\end{array}$ \\
\hline Degree of penalty $C$ & $\begin{array}{c}0.416 \\
(0.552)\end{array}$ & $\begin{array}{c}0.665 \\
(0.483)\end{array}$ & $\begin{array}{r}-0.648 \\
(0.359)\end{array}$ & $\begin{array}{r}-0.398 \\
(0.374)\end{array}$ \\
\hline $\begin{array}{l}\text { Probability of being } \\
\text { punished } p\end{array}$ & $\begin{array}{c}-0.017 * * \\
(0.006)\end{array}$ & $\begin{array}{r}-0.013 \dagger \\
(0.007)\end{array}$ & $\begin{array}{r}-0.013^{*} \\
(0.005)\end{array}$ & $\begin{array}{c}-0.011^{*} \\
(0.005)\end{array}$ \\
\hline Law obedience & & $\begin{array}{l}-1.493 * * * \\
(0.497)\end{array}$ & & $\begin{array}{c}-1.097 * * \\
(0.354)\end{array}$ \\
\hline Pseudo- $R^{2}$ (McFadden) & 0.123 & 0.173 & 0.073 & 0.101 \\
\hline$N$ & 307 & 307 & 728 & 728 \\
\hline Percentage of offences & 8.1 & 8.1 & 5.6 & 5.6 \\
\hline
\end{tabular}

Notes: Logistic regression (in brackets: standard error of coefficients); ${ }^{*} p \leq 0.05$; ** $p \leq 0.01 ; * * * p \leq 0.001 ; \dagger p \leq 0.1$.

Source: ALLBUS 1990 - own calculations.

as an action alternative so that, owing to an insufficient number of cases among the potential shoplifters, no assessments could be accomplished.

The utility effect, however, disappears if, together with obedience to the law, the effectiveness of primary or secondary socialization is examined (Model 2). The probability of success exerts a (fairly) stable influence on the intention of committing shoplifting, while, contrary to the sixth hypothesis, the influence is more distinct among the middle classes.

The expected degree of penalty for shoplifting is of little importance but our data shows that among all social classes the subjectively expected probability of being caught stealing and being punished for it has a deterring effect. However, the second hypothesis assumed that due to the accruing opportunity costs, this effect is stronger among the lower social classes than among the higher social classes. 
Biased evaluations are probably not the decisive factor in the case of shoplifting, but rather fairly realistic and heuristic assessments of being caught stealing, even though shoplifting does not necessarily appear to be a widespread 'blue collar crime'. The low percentage of 8 percent of individuals from lower classes who would steal can be a statistical artifact since the ALLBUS survey only interviewed individuals of age - however, unlike tax fraud, shoplifting is also often committed by children and adolescents.

\section{Summary and Conclusion}

It was the objective of this article to extend and empirically employ the economic theory of criminal behavior by Gary S. Becker with particular consideration of the relationship between social class and criminality and from the perspective of the theory of subjectively expected utility (SEU). The starting point was Becker's (1968) assumption that criminality is mainly an individual's problem and therefore could not be made explicable by classical sociological factors. Accordingly, it was sufficient to merely refer to the economic calculation of the criminal behavior's benefit, the expected degree of penalty and the subjective probability of being caught as central factors. However, from a sociological perspective it remains unclear how social circumstances contribute to an individual's decision for law-abiding or criminal behavior. The hitherto open explanation of a relationship between social class and criminality is cited as an example.

Thus, on the one hand, propositions of the 'Anomie Theory' (Merton 1968), the 'Theory of Opportunity Structures' (Cloward 1968) and the 'Theory of Differential Association' (Sutherland and Cressey 1966), all compatible with rational choice approaches, were integrated into the basic model. On the other hand, the perception and assessment of incentives and opportunities were connected with the process of evaluation and decision making. It was then argued that individuals do not only calculate probabilities of being caught and punished but also probabilities of success if, in a particular situation, they have to decide for or against an offence. Defining their social situation (that is, before the actual decision and action) individuals choose the most eligible action alternatives so that criminal behavior can be excluded in the first place, if internalized norms prohibit criminal behavior in general. This pre-selection 
constitutes an important explanation for criminality in general and for the relationship between social class and criminality in particular. Because internalized norms restrict the set of alternatives, certain action alternatives are not similarly promising for all classes. Starting out from the extended explanation model and due to the class-varying incentives and opportunities, specific hypotheses about the socialstructurally varying calculations of expectations were developed, which are capable of clarifying the decision for an offence as well as explaining the class-varying tendency towards certain offences.

The empirical analyses were based on cross-sectional data from the ALLBUS of the years 1990 and 2000. Due to the available data, the analyses are restricted to the offences of 'shoplifting' and 'tax fraud'. If the often-postulated general (negative) relationship between class and criminality exists, the members of the lower classes should be over-represented in the offender population for both offences. Since this is not the case, however, we cannot identify a general relationship between social class and criminal behavior. There may be a higher percentage of shoplifters in the lower class than in the middle and upper classes but for the offence of tax fraud the exact opposite can be found, i.e. the percentage of delinquents from the upper class is higher than in the other classes.

From our point of view, the 'myth' of a general relationship between social class and criminality (Dunaway et al. 2000; Tittle et al. 1978) also results from the fact that, as shown by the findings, different offences are mingled in the analyses. However, they each have different social preconditions and implicated processes of evaluation and decision making, which yield different results for the different social classes. It is particularly the incentives, opportunity structures and socialization effects which play an important role for the explanation of the relationship between social structure and criminality.

However, the basic mechanisms, the structure of evaluating, the decision and action processes are always uniform, and are also in the case of criminal behavior in accordance with the logic of rational choice. It could be ascertained empirically that the economic model by Becker (1968) is workable, even though incomplete from a sociological perspective. Our SEU model proved to be superior to the economic basic model in several respects. First, it is more effective in predicting people's criminal behavior out of theoretical considerations if all decisive determinants of the individual process of evaluation and decision making are known. Second, the quality of the SEU 
model's assessments is higher than that of the model by Becker (1968) since it explains more variance of the dependent variable (see the pseudo- $R^{2}$-values in Tables 4 and 5). Third, examining the social situation's relevant boundary conditions, instead of the subjectively expected probabilities of success and failure, proved to be the important variables in comparison with the expected values of utilities and costs. Fourth, the economic model's theoretical extensions into the SEU model proved to be empirically valid. Relevant propositions of sociological approaches like the anomie theory (Merton 1968), the theory of differential association (Sutherland and Cressey 1966) and the opportunity structure theory (Cloward 1968), as well as propositions from socialization theory could consistently be integrated.

In conclusion, two remarks for future research shall be added. Empirical application of action-theoretical models requires data that are more informative. Their quality has to be improved with regard to the measurement of theoretical constructs and the entire evaluation and action process. Additionally, Sampson and Laub (1992) also show that for criminal behavior, longitudinal data provide more informative fundamentals for empirical research than cross-sectional data. By using longitudinal data, in particular evenorientated process data, it would be possible to reproduce causes for criminal behavior in a more realistic way. Moreover, such data make it possible to examine the durability of causes for criminal behavior or even to follow 'criminal careers'. On the other hand, it is advisable in terms of cumulative research to employ the SEU model of (criminal) behavior for offences other than tax fraud or shoplifting in order to substantiate the conclusions of this work. This strategy finally promises the further development of the theoretical considerations into a general model of delinquent behavior as a special case of rational choice and experienced everyday behavior.

\section{NOTES}

1. Diverse reasons are mentioned for the different and inconsistent findings about the relationship between social class and criminal behavior. On the one hand, methodical deficiencies in the empirical analyses are blamed if official aggregate data instead of individual data with self-reported behaviors or different definitions of delinquency and social class or different measurement concepts are utilized (Hindelang et al. 1979; Tittle and Meier 1990). Moreover, there seem 
to be biased findings owing to selective samples and lack of validity or reliability of data (Thornberry and Farnworth 1982). On the other hand theoretical deficiencies are emphasized (e.g. Tittle 1983). Thus Dunaway et al. (2000) and Tittle et al. (1978) unanimously speak about a myth, since the relationship between social class and delinquent behavior is based upon everyday hypotheses and prejudice, which are upheld even if findings contradict these opinions. Accordingly, attempts to explain criminal behavior with the concept of social class have to be reconsidered (e.g., Albrecht and Howe 1992; Braithwaite 1981).

2. However, it is also considered that a high socioeconomic status might be correlated with the individual's inclination to crime. For example, Wright et al. (1999) found in a longitudinal design that a low socioeconomic status promoted delinquency by increasing alienation, financial strain, and decreasing occupational opportunities, whereas a high socioeconomic status promoted delinquency by increasing risk taking and decreasing conventional, pro-social values.

3. Naturally, there are more sociological theories of differing behavior such as the labeling approach (Lemert 1967) or the general theory of crime (GTOC) by Gottfredson and Hirschi (1990). However, they are not included in this article since the focus is directed to the relationship between social class and criminality. At least the main arguments of both approaches - the stigmatizing in the labeling approach and the social opportunities in the GTOC - can be integrated into Becker's (1968) approach to the considerations about the costs of opportunities if the theoretical ballast of 'role adoption' and 'self-control' is jettisoned. Nagin and Paternoster (1993: 467) have combined poor self-control and situational factors. In a sample of college undergraduates they found that even after considering differences of self-control, 'there was evidence to suggest that the attractiveness of the crime target, the ease of committing the crime with minimum risk, and perceptions of the costs and benefits of committing the crime were all significantly related to offending decisions'. Furthermore, Seipel (1999) found (in an experimental design) that the level of self-control has only very limited explanatory power if the 'crime opportunity' is controlled for.

4. Here we restrict ourselves to criminal behavior patterns, which are not demanded on a market. Criminal activities, which comprise a market demand (e.g. ordered murder or drug distribution) underlie the same conditions as any other gainful occupation - except that they are carried out on an illegal market.

5. Benefits and costs can be of physical as well as psychological value for the actor. 'Sex and excitement' are examples of it. Thus, Katz (1988: 3) assumes that shoplifting (apart from material benefits) yields 'sneaky thrills'.

6. According to Becker (1968), the subjective assessment of these factors depends on the individual attitude towards risks. Thus, actors who are prepared to take risks are deterred by the probability of being caught rather than by the level of penalty. In the case of risk-neutral actors, the impacts of probability and penalty can compensate while actors who avoid risks are deterred by the effect of heavier penalties rather than by the probability of being caught. Becker draws the unfounded conclusion that criminal actors are more likely to take risks and that therefore the probability of being caught is generally more important than the penalty. The latter assumption may be supported by game-theoretical considerations (Bueno de Mesquita and Cohen 1995) and empirical studies. However, this psychological supplementary assumption is inconsistent with the economic approach to criminal behavior and generally with the logic of rational choice 
theories since there would be a psychological disposition of criminals then, which distinguishes them from law-abiding citizens.

7. Criminals can have an advantage here - in particular, criminals who have repeatedly committed certain offences since they may be able to better assess the number of unreported cases (Curti 1998: 34). If these criminals additionally act in a criminal environment, they can also assess their accomplices' probabilities of success relatively exactly. Thus, the uncertainty of the parameter $p$ for repeat offenders who act in a criminal environment (differential association) is relatively low. The calculation of the expected value for criminal acting is more successful. This explanation of criminal careers is compatible with the economic approach. It is not even necessary to fall back on theoretically problematic constructions such as role adoption or the principle of secondary deviance as is the case in the labeling approach. These reflections come to the obvious conclusion that - if it is not possible to solve every offence - the probability of being caught should be uncertain in order to keep the calculation of the expected values for criminal activities as uncertain as possible, thus preventing criminal behavior.

8. Opportunity costs comprise the missed benefit from all the other action alternatives not chosen (for example, the missed income from legal activities that cannot be carried out during the criminal act). These opportunity costs always arise if an illegal action alternative is chosen - regardless of whether or not the actor is caught. Thus, the opportunity costs of criminal activities are mainly determined by the available occupational alternatives - aspects of the anomie theory can also be integrated into the economical approach through the concept of opportunity costs. If the criminal is caught and arrested, he additionally misses the income from possible legal activities, which cannot be carried out during the detainment. Since legal incomes vary amongst actors, the opportunity costs vary correspondingly as well. In addition, different legal incomes can result in identical opportunity costs if the periods of imprisonment are of different duration. The costs of detainment are much higher for an actor who generates a high income in legal occupation than for example for an unemployed person. Moreover, imprisonment limits the material quality of life, more so for prosperous individuals than for less prosperous ones. This speaks to the assumption that concerning opportunity costs, certain groups have different incentives for offences than members of other groups. Negative correlations between income and criminal behavior or positive correlations between unemployment and the perpetration of offences can be found in a multitude of studies (e.g. Grogger 1991, 1998; Pezzin 1995; Uggen and Thompson 1999). Transaction costs of criminal behavior must not be underestimated. This comprises costs for concealing the offence and for its realization (for example the provision of a getaway car or a weapon) as well as transaction costs, which accrue from illegality itself. The transaction costs are lower for actors with criminal experience or for actors who have learnt criminal behavior than for beginners or 'amateurs'.

9. Generally, this point of view clarifies the existence of inconsistent findings regarding the relationship between rates of criminality and the degree of penalty. Apart from the methodical problems connected with the statistical analysis of the official statistics' aggregate data, the concept of general deterrence often ignores the objective probabilities of solving a crime. The degrees of penalty as exogenous factors are irrelevant for the description and explanation of criminal behavior 
since they (possibly) deviate considerably from the subjectively expected probabilities and degrees of penalty. Furthermore, the spread of secured knowledge of the degrees of penalty for diverse criminal offences remains out of consideration. Thus a variety of empirical studies show that the probability of being caught and punished rather than the degree of penalty are decisive for not contemplating a criminal offence (e.g. Grasmick and Bursik 1990: 840; Niggli 1994: 92-3; Silberman 1976: 443).

10. The aim is not an objectively assessable maximization of utility, as assumed in the economic approaches of voting, but merely to attain a subjectively satisfying utility. In order to maximize one's own utility in a complex situation, an individual must obtain and process a variety of information. Since both the inquiry and the processing of information involve costs, the attainment of the boundary utility of information will result in the actor's ceasing to search for further information, if the available information is sufficient for a cost-benefit calculation whose result pledges a satisfying utility (Simon 1993). The understanding of the bounded rationality is however not contradictory with the core of rational choice theories but considers that an individual is capable of dealing with scarce resources such as time and information in a reasonable way (Esser 1999, 1996).

11. Actors with internal control beliefs expect to have influence on events by their actions. Actors with external control beliefs think that the results depend on factors outside themselves. Control beliefs emerge dependent on the individual learning history. Someone who is socialized in a criminal environment is supposed to exhibit rather internal control beliefs regarding certain offences. These assumptions, based on the theory of learning, are not only compatible with the theory of criminal behavior but can be integrated into this theory without problems (Niggli 1994: 88).

12. Tyler (1990: 4) assumes that internalized norms prevent criminal behavior - not dependent on external factors such as threat of punishment. He distinguishes between 'personal morality' (the actor obeys the law since he considers it to be just) and 'legitimacy' (the actor obeys the law since he believes in the legislature's right to control individual behavior).

13. Niggli (1994: 86) shows that such a restriction can be consistent with the basic assumptions of the SEU theory: 'By such a definition rationality does not dictate what can be concluded, but only what cannot'. The actor's learning processes (socialization) provoke a restricted perceptual ability for - legal or illegal action possibilities, which can be analytically interpreted as a change of preference towards illegal (legal) alternatives. In other words: Differential contacts with criminal actors generate a perception filter that systematically makes the opportunity costs for criminal activities appear lower.

14. According to the learning theory, the peer group as the actor's normative reference group is of great importance here. 'Informal reactions of the specific social network of which the actor is part should be much more important than general social ideals and formal reactions, because the latter do not concern the individual directly. Finally, to the extent that moral beliefs are part of the actor's bond to his primary social network, they should be very important, too. . . . Since these beliefs and morale take effect only as far as they are personally valued, it would in fact be "irrational", that is inconsistent, to believe something 
but act contrary to it' (Niggli 1994: 92; see also Frey and Opp 1979: 289; McCarthy 2002: 426).

15. Note, however, that Bachman et al. (1992) analyzed sexual assault and rape, offences that are morally condemned by most individuals. In accordance with Bachman et al. (1992: 365), therefore, it is questionable if these results could be generalized. It might be quite interesting if moral beliefs also matter for morally less critical offences like shoplifting and tax evasion.

16. In order to employ the data of the ALLBUS 2000 for analyses on the individual level, the over-sampling for East Germany is compensated - as suggested by ZUMA - by making a disproportional weighting on the personal level (Koch et al. 2001).

17. The questionnaires in the ALLBUS 1990 and 2000 were split. With regard to delinquency, both groups were presented differently formulated questions. For the review of the theoretical model of tax fraud, the ALLBUS 1990 only allows an analysis with the 1461 interviewees from the second split. The multivariate analysis of shoplifting, however, comprises an intersection from both split groups. For the multivariate analyses, the ALLBUS 2000 could consider only the 1525 people from the second split. For the descriptive analyses, the 1613 people from the first split were included.

18. In 1990, 2812 out of the 3051 people completed the questionnaire about their delinquent behavior. In the ALLBUS 2000, approximately 87.5 percent of the 1605 people who were asked about delinquency filled in the confidential questionnaire. Capturing the previous and future delinquent behavior (except tax evasion), the pre-test, conducted by the ZUMA in the preliminary stages of the ALLBUS 1990 survey, did not reveal significant differences between the oral inquiry and the sealed-envelope technique (Wasmer et al. 1991: 11-12). Thus the data on tax fraud should be interpreted cautiously, which, however, is advisable for all studies of this topic.

19. Pogarsky (2004) conducted a survey about drinking and driving among American university students. At the end of the survey, there was a short trivia quiz. The experimental design gave the respondents the opportunity to cheat on the quiz. Pogarsky (2004: 123) summarizes the result: 'Cheating during the experiment remains strongly and significantly related to projected drinking and driving'. One could argue that these are different types of offences (driving while being intoxicated versus cheating on a quiz), but on the other side this experiment provides strong evidence that intended and actual offending is correlated.

20. Given these questions about the subjectively expected probabilities, the respondents are allowed to estimate their own certainty level instead of experimentally manipulate punishment certainty. This is to avoid the artificiality of furnishing detection probabilities that the respondents may find unrealistic (see Klepper and Nagin (1989) for further details).

21. For both offences, this variable for the degree of penalty constitutes an approximation to the fact that, from the asked person's perspective, this punishment is also expected for the corresponding offence (Grasmick and Bryjak 1990: 486; Opp 1989: 426). It underestimates the accruing costs if there is neither information about informal sanctions nor information about the opportunity costs even if the height of the earned income is controlled (e.g. Bishop 1984; Davis 1988: 384; Grasmick and Bryjak 1990; Meier and Johnson 1977). It remains unclear whether and to what extent the real penalties for both offences are 
known and whether appropriate degrees of penalty are demanded in the subjective assessment (Erickson et al. 1977: 307). Due to a lack of information, it also remains unsolved to what extent people take into account the possibility of an externalization of the accruing costs in their consideration of action alternatives. Thus, the consequences of individual tax evasion are generalized (Friedrichs 1997: 477).

22. This first impression of the distribution of both offences has to be qualified in two ways. On the one hand, the frequency of the offences is left out of consideration in the case of repeat offenders, thus underestimating the distribution of that offence. On the other hand, a comparison with official data reveals the rather large estimated number of unknown cases of shoplifting. Therefore, the crime rate is systematically underestimated. According to the police criminal statistic, 784 cases of shoplifting were reported for every 100,000 inhabitants in 1990, 96 percent of which were solved. In the year 2000 - with a success rate of 94 percent of the cases solved - 732 cases of shoplifting were registered for every 100,000 inhabitants.

23. The central question of whether lower classes are more criminal than higher classes is irrelevant if the corresponding reasons for it and the damage emerging to the society are left out of consideration (e.g. Becker 1968). Empirical results for Germany reveal that 'white collar' criminality, primarily committed by the middle and upper classes, causes higher material damage than 'blue collar' crimes, even if expenses for police, jurisdiction and the enforcement of sentences are charged (e.g. Federal Ministry of the Interior 2001: 132).

24. Since only individuals liable to income tax are capable of evading taxes, only gainful employees who gave information about the amount of their monthly net income are considered. Since this restriction was expected to yield a sample selection bias (Schömann and Becker 2002), which also evokes biased estimation results for multiple regressions, the correction method by Heckman (1979) was employed (e.g. Becker 2003). Since there were no biased samples and the estimations did not differ significantly with or without Heckman-correction, the uncorrected estimations were used. We are aware of the fact that the actual dimension of tax evasion is recorded incompletely since corporate actors who are not considered here can also commit tax fraud.

25. Note that we do not insert interaction terms between law obedience and Rational Choice variables (such as expected utility or probability of being detected or successful). Contrary to our theoretical assumptions, interaction terms would imply that potential offenders interpret the breaking of norms just as a weight for costs and benefits. However, we propose that norms provide a 'cognitive' filter for appropriate and inappropriate alternatives of action, respectively.

\section{REFERENCES}

Albrecht, G. and C.-W. Howe. 1992. 'Soziale Schicht und Delinquenz. Verwischte Spur oder falsche Fährte?' Kölner Zeitschrift für Soziologie und Sozialpsychologie 44: 697-730.

Bachman, R., R. Paternoster and S. Ward. 1992. 'The Rationality of Sexual Offending: Testing a Deterrence / Rational Choice Conception of Sexual Assault.' Law \& Society Review 26: 343-72. 
Bandura, A. 2001. 'Social Cognitive Theory: An Agentic Perspective.' Annual Review of Psychology 52: 1-26.

Becker, G.S. 1968. 'Crime and Punishment: An Economic Approach.' Journal of Political Economy 76: 169-217.

Becker, R. 2003. 'Educational Expansion and Persistent Inequalities of Education: Utilising the Subjective Expected Utility Theory to Explain the Increasing Participation Rates in Upper Secondary School in the Federal Republic of Germany.' European Sociological Review 19: 1-24.

Becker, R. and R. Günther. 2004. 'Selektives Antwortverhalten bei Fragen zum delinquenten Handeln. Eine empirische Studie über die Wirksamkeit der "sealed envelope technique" bei selbst berichteter Delinquenz mit Daten des ALLBUS 2000.' ZUMA-Nachrichten 54 28: 39-59.

Birbeck, C. and G. LaFree. 1993. 'The Situational Analysis of Crime and Deviance.' Annual Review of Sociology 19: 113-37.

Bishop, D.M. 1984. 'Legal and Extralegal Barriers to Delinquency.' Criminology 22: 403-19.

Blossfeld, H.-P. 1996. 'Macro-Sociology, Rational Choice Theory, and Time. A Theoretical Perspective on the Empirical Analysis of Social Processes.' European Sociological Review 12: 181-206.

Braithwaite, J. 1981. 'The Myth of Social Class and Criminality Reconsidered.' American Sociological Review 46: 36-57.

Bueno de Mesquita, B. and L.E. Cohen. 1995. 'Self-interest, Equity, and Self-control: A Game-theoretic Analysis of Criminal Decisions.' Criminology 33: 483-517.

Cloward, R. 1968. 'Illegitime Mittel, Anomie und Abweichendes Verhalten.' In Kriminalsoziologie, ed. F. Sack, pp. 314-39. Frankfurt am Main: Akademische Verlagsgesellschaft.

Coleman, J.W. 1985. The Criminal Elite. The Sociology of White Collar Crime. New York: St. Martin's Press.

Cornish, D.B. and R.V. Clarke. 1987. 'Understanding Crime Displacement: An Application of Rational Choice Theory.' Criminology 25: 933-47.

Curti, H. 1998. Abschreckung durch Strafe. Eine ökonomische Analyse der Kriminalität. Konstanz: DUV.

Davis, M.L. 1988. 'Time and Punishment: An Intertemporal Model of Crime.' Journal of Political Economy 96: 383-90.

Diekmann, A. 1980. Die Befolgung von Gesetzen. Empirische Untersuchungen zu einer rechtssoziologischen Theorie. Berlin: Duncker and Humblot.

Dillman, D.A. 2000. Mail and Internet Surveys. The Tailored Design Method. 2nd edition. New York: Wiley \& Sons.

Dunaway, G.R., F.T. Cullen, V.S. Burton, Jr. and D.T. Evans. 2000. 'The Myth of Social Class and Crime Revisited: An Examination of Class and Adult Criminality.' Criminology 38: 589-623.

Erickson, M.L., J.P. Gibbs and G.F. Jensen. 1977. 'The Deterrence Doctrine and the Perceived Certainty of Legal Punishment.' American Sociological Review 42: 305-17.

Esser, H. 1986. 'Können Befragte lügen? Zum Konzept des "wahren Wertes” im Rahmen der handlungstheoretischen Erklärung von Situationseinflüssen bei der Befragung.' Kölner Zeitschrift für Soziologie und Sozialpsychologie 38: 314-36.

Esser, H. 1996a. 'What is wrong with "Variable Sociology"?' European Sociological Review 12: 159-66. 
Esser, H. 1996b. 'Die Definition der Situation.' Kölner Zeitschrift für Soziologie und Sozialpsychologie 48: 1-35.

Esser, H. 1999. Soziologie. Spezielle Grundlagen. Band 1: Situationslogik und Handeln. Frankfurt am Main: Campus.

Federal Ministry of the Interior [Bundesministerium des Inneren] (Ed.), 2001. Erster Periodischer Sicherheitsbericht. Berlin: BMfI.

Frey, B.S. and K.-D. Opp. 1979. 'Anomie, Nutzen und Kosten. Eine Konfrontierung der Anomietheorie mit ökonomischen Hypothesen.' Soziale Welt 30: 275-94.

Friedrichs, J. 1997. 'Normenpluralität und abweichendes Verhalten. Eine theoretische und empirische Analyse.' In Was treibt die Gesellschaft auseinander?, ed. W. Heitmeyer, pp. 473-505. Frankfurt am Main: Suhrkamp.

Gottfredson, M.R. and T. Hirschi. 1990. A General Theory of Crime. Stanford, CA: Stanford University Press.

Grasmick, H.G. and G. Bryjak. 1990. 'The Deterrent Effect of Perceived Severity of Punishment.' Social Forces 59: 471-91.

Grasmick, H.G. and R.J. Bursik Jr. 1990. 'Conscience, Significant Others, and Rational Choice: Extending the Deterrence Model.' Law and Society Review 24: $837-61$.

Grogger, J.T. 1991. 'Certainty vs. Severity of Punishment.' Economic Inquiry 29: 297310 .

Grogger, J.T. 1998. 'Market Wages and Youth Crime.' Journal of Labor Economics 16: 756-91.

Heckhausen, J. and R. Schulz. 1993. 'Optimisation by Selection and Compensation: Balancing Primary and Secondary Control in Life Span Development.' International Journal of Behavioral Development 16: 287-303.

Heckman, J.J. 1979. 'Sample Selection Bias as a Specification Error.' Econometrica 47: $153-61$.

Hedström, P. and R. Swedberg. 1996. 'Social Mechanism.' Acta Sociologica 39: 281308.

Hindelang, M.J., T. Hirschi and J.G. Weis. 1979. 'Correlates of Delinquency: The Illusion of Discrepancy between Self-report and Official Measures.' American Sociological Review 44: 995-1014.

Homel, R. 1983. 'Drivers Who Drink and Rational Choice: Random Breath Testing and the Process of Deterrence.' In Routine Activity and Rational Choice, eds R.V. Clarke and M. Felson, pp. 59-84. New Brunswick, NY: Transaction/Sigma Publishers.

Katz, J. 1988. Seductions of Crime. New York: Basic Books.

Klepper, W. and D.S. Nagin. 1989. 'Tax Compliance and Perceptions of the Risk of Detection and Criminal Prosecution.' Law \& Society Review 23: 209-40.

Koch, A., M. Wasmer, J. Harkness and E. Scholz. 2001. Konzeption und Durchführung der 'Allgemeinen Bevölkerungsumfrage der Sozialwissenschaften' (ALLBUS) 2000. Mannheim: ZUMA-Methodenbericht 2001/05.

Lemert, E.M. 1967. Human Deviance, Social Problems, and Social Control. Englewood Cliffs, NJ: Prentice-Hall.

McCarthy, B. 2002. 'New Economics of Sociological Criminology.' Annual Review of Sociology 28: 417-42.

McKenzie, R.B. and G. Tullock. 1984. The New World of Economics. New York: McGraw-Hill. 
Meier, R.F. and W.T. Johnson. 1977. 'Deterrence as Social Control: The Legal and Extralegal Production of Conformity.' American Sociological Review 42: 292-304.

Merton, R.K. 1968. 'Sozialstruktur und Anomie.' In Kriminalsoziologie, ed. F. Sack, pp. 283-314. Frankfurt am Main: Akademische Verlagsgesellschaft.

Nagin, D.S. and R. Paternoster. 1993. 'Enduring Individual Differences and Rational Choice Theories of Crime.' Law \& Society Review 27: 467-9.

Niggli, M.A. 1994. 'Rational Choice Theory and Crime Prevention.' Studies on Crime and Crime Prevention 3: 83-103.

Opp, K.-D. 1974. Abweichendes Verhalten und Gesellschaftsstruktur. Darmstadt und Neuwied: Luchterhand.

Opp, K.-D. 1989. 'The Economics of Crime and the Sociology of Deviant Behavior. A Theoretical Confrontation of Basic Propositions.' Kyklos 42: 405-30.

Paternoster, R. 1989. 'Decisions to Participate in and Desist from Four Types of Common Delinquency: Deterrence and the Rational Choice Perspective.' Law and Society 23: 7-40.

Paternoster, R., L.E. Saltzman, T.G. Chiricos and G.P. Waldo. 1982. 'Perceived Risk and Deterrence: Methodological Artifacts in Perceptual Deterrence Research.' Journal of Criminal Law and Criminology 73: 1238-58.

Pezzin, L.E. 1995. 'Earnings Prospects, Matching Effects, and the Decision to Terminate a Criminal Career.' Journal of Quantitative Criminology 11: 29-50.

Piliavin, I., C. Thornton, R. Gartner and R.L. Matsueda. 1986. 'Crime, Deterrence, and Rational Choice.' American Sociological Review 51: 101-19.

Pogarsky, G. 2004. 'Projected Offending and Contemporaneous Rule-violation: Implications for Heterotypic Continuity.' Criminology 42: 111-35.

Sampson, R.J. and J.H. Laub. 1992. 'Crime and Deviance in the Life Course.' Annual Review of Sociology 18: 63-84.

Schömann, K. and R. Becker, 2002. 'Access to Training for the Unemployed in Germany.' In Education, Training and Employment Transitions: Transitional Labour Markets in the European Union, eds K. Schömann and J. O'Connell Philip, pp. 153-85. Cheltenham: Edward Elgar.

Seipel, C. 1999. 'Die Bedeutung von Gelegenheitsstrukturen in der General Theory of Crime von Michael R. Gottfredson und Travis Hischi.' Soziale Probleme 10: 144-65.

Silberman, M. 1976. 'Toward a Theory of Criminal Deterrence.' American Sociological Review 41: 442-61.

Simon, H.A., 1993. Homo rationalis. Die Vernunft im menschlichen Leben. Frankfurt am Main: Campus.

Sudman, S. and N.M. Bradburn. 1974. Response Effects in Surveys: A Review and Synthesis, Chicago, IL: Aldine.

Sudman, S., N.M. Bradburn and N. Schwarz. 1996. Thinking about Answers. The Application of Cognitive Processes to Survey Methodology. San Francisco, CA: Jossey-Bass.

Sutherland, E.H. and D. Cressey. 1966. Principles of Criminology. Philadelphia, PA and New York: Lippincott.

Sykes, G.M. 1978. Criminology. New York: Harcourt Brace Jovanovich.

Thornberry, T.P. and M. Farnworth. 1982. 'Social Correlates of Criminal Involvement: Further Evidence on the Relationship between Social Status and Criminal Behavior.' American Sociological Review 47: 505-18. 
Tittle, C.R. 1983. 'Social Class and Criminal Behavior: A Critique of the Theoretical Foundation.' Social Forces 62: 334-58.

Tittle, C.R. and R.F. Meier. 1990. 'Specifying the SES/Delinquency Relationship.' Criminology 28: 271-99.

Tittle, C.R., W.J. Villemez and D.S. Smith. 1978. 'The Myth of Social Class and Criminality: An Empirical Assessment of the Empirical Evidence.' American Sociological Review 43: 643-56.

Tyler, T.R. 1997. 'Procedural Fairness and Compliance with the Law.' Swiss Journal of Economics and Statistics 133: 219-40.

Uggen, C. and M. Thompson. 1999. 'The Socioeconomic Determinants of Ill-gotten Gains: Within-person Changes in Drug Use and Illegal Earnings.' Paper presented at the 94th Annual Meeting of the American Sociological Association, Chicago, Illinois, 6-10 August.

Urban, D. 1993. Logit-Analyse. Statistische Verfahren zur Analyse von Modellen mit qualitativen Response-Variablen. Stuttgart: Fischer.

Voss, T. and M. Abraham. 2000. 'Rational Choice Theory in Sociology: A Survey.' In International Handbook of Sociology, ed. S. R. Quah, pp. 50-83. London: SAGE.

Wasmer, M., A. Koch and M. Wiedenbeck, 1991. Methodenbericht zur 'Allgemeinen Bevölkerungsumfrage der Sozialwissenschaften' (ALLBUS) 1990. Mannheim: ZUMA-Arbeitsbericht 91/13.

Wittig, P. 1993. Der rationale Verbrecher. Der ökonomische Ansatz zur Erklärung kriminellen Verhaltens. Berlin: Duncker and Humblot.

Wright, B.R., A. Caspi, T.E. Moffitt, R.A. Miech and P.A. Silva. 1999. 'Reconsidering the Relationship between SES and Delinquency: Causation but not Correlation.' Criminology 37: 175-95

ROLF BECKER (corresponding author) is chair and director of the Department of Sociology of Education at the University of Berne, Switzerland. He studied sociology, political sciences, social psychology and contemporary history at the University of Mannheim, and received his PhD in 1993 from the Max Planck Institute of Human Development and Education in Berlin and Free University of Berlin. His fields of research interest are sociology of education, life-course research, social stratification and social mobility, sociological methods and rational choice theory. Recent publications include articles in Quality \& Quantity, German Politics and European Sociological Review.

ADDRESS: University of Berne, Department of Sociology of Education, Muessmattstrasse 27, 3012 Berne, Switzerland [email: rolf.becker@sis.unibe.ch].

GUIDO MEHLKOP is assistant professor of sociology at the Dresden University of Technology, Germany. He studied sociology, educational sciences and political sciences at the University of Bonn, Germany, from which he received his $\mathrm{PhD}$ in 2001. His 
fields of interest are sociocultural and institutional determinants of economic development, inequality, and corruption in cross-time and cross-section perspective; the economics of crime; military sociology; and rational choice and public choice theory. He has published (with Peter Graeff) in Comparative Sociology.

ADDRESS: Dresden University of Technology, Institute of Sociology, 01062 Dresden, Germany

[email: guido.mehlkop@mailbox.tu-dresden.de]. 